\title{
Classification of Iberian pigs according to intensive feeding by chemsensor
}

\author{
By J.A. Carrasco ${ }^{a, *}$ and J.P. Duque ${ }^{b}$ \\ ${ }^{a}$ Departamento de Procesos, Instituto de Ciencia y Tecnología de Alimentos y Nutrición (ICTAN) CSIC. \\ C/ José Antonio Novais, 10. 28040 Madrid

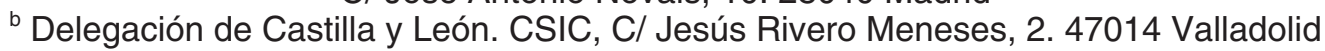 \\ * Corresponding author: atanasio @ictan.csic.es
}

\section{RESUMEN}

Clasificación de cerdos ibéricos en función de su alimentación mediante ChemSensor

La calidad de la carne de cerdo está muy relacionada con la alimentación que ha tenido en su fase de cebo, por lo que se están desarrollando métodos analíticos que determinen la misma. Entre ellos se encuentra el ChemSensor o Sensor químico que incorpora análisis multivariante a la tecnología de cromatografía de gases con detector de masas. Esta técnica permite agrupar alimentos por similitudes y mediante un modelo matemático proceder a su clasificación. Mediante un modelo matemático de predicción consigue clasificar muestras incógnitas y definir la alimentación que ha tenido el cerdo en su fase de engorde. Se han clasificado cerdos de dos campañas y a pesar de obtener una buena clasificación, se ha constatado el grado de dificultad de predecir la alimentación por el elevado número de clases contemplado en la norma como por las propias costumbres de los ganaderos en sus técnicas productivas así como la variabilidad de los piensos utilizados. Reducir el número de clases a bellota y pienso, ayudaría a clarificar el mercado del cerdo ibérico.

PALABRAS CLAVE: Alimentos - Análisis multivariante - Cerdo - ChemSensor - Clasificación - Cromatografía de gases-masas - Jamón.

\section{SUMMARY}

Classification of Iberian pigs according to intensive feeding by chemsensor

Pork quality is highly dependent on intensive feeding during the fattening step. For that reason a large number of analytical methods are continuously being developed to evaluate it. Among them is the ChemSensor method which comprises a multivariate analysis in a gas chromatograph with a mass spectrometry detection device. This technique affords a feeding grouping of similar features, leading to a classification of meat quality. Using a mathematical predictive model for new, unknown samples the right classification is achieved as well as the type of intensive feeding used during the fattening of pigs. Pigs from two campaignes have been classificated with good results, although a certain difficulty in prediction was found due to the excessively large number of classes stated in the official Quality Iberian Standards, and the customs of the farmers themselves in relation with the handling of animals and the intensive feeding provided. Narrowing the number of classes down to two, "Bellota" and "Pienso", would contribute to a better understanding in the Iberian pig market.
KEY-WORDS: ChemSensor-Classification - Food-Gas Chromatography-Mass Spectrometry - Jam - Multivariate analysis - Pig.

\section{INTRODUCTION}

Iberian pig meat is highly valued since its outstanding quality comes from an Oleic Acid and PUFA enriched fatty acid profile. There are several production systems, notably those based on extensive livestock that provide animals with reputed characteristics owing to their feeding regime with acorns and the physical exercise they get. Spain has an ecosystem located in the western regions formed by oaks and cork trees known as "meadow" - an ideal environment for extensive pig production. With over fifteen thousand square kilometers, the meadow supplies all the acorn feeding necessary for pigs. It also helps to maintain the Iberian pig breed and provides an irreplaceable raw material for the meat industry which is unique in the world for the quality of its fine products such as ham and the Iberian loins. There is, however, a high differential cost between the operating system based on food provided by the natural environment and full intensive systems (intensive feeding-fattening) used by other farmers, which impacts greatly on the quality and price of elaborated products.

The Spanish Administration has established a Quality Iberian Standard for pigs which classifies them into several groups according to their feeding system. These groups have changed over time, and a new modification of this standard has appeared recently. At the time of the present work the classification that is in force states up to four types of animals: Bellota pigs, Recebo pigs, Standard Extensive-Feeding (Pienso extensivo) and Standard Intensive Feeding (Pienso intensivo), according to the intensive feeding at the final fattening step.

In order to analytically assess the above classification, some methods have been developed based on different techniques within the scope of a collaborative research project funded by the Spanish Instituto Nacional de Investigación y Tecnología Agraria y Alimentaria (INIA). Among 
these selected methods, the chemical sensor technique (ChemSensor) is included.

The ChemSensor technique is based on a gas chromatography-mass spectrometry (GC-MS) (Pérez Pavón et al., 2006; López-Feria et al., 2008; Marsili 2011). This technique uses the mass fragment abundances $\mathrm{m} / \mathrm{z}$ (mass/ charge) from 40 to 500 performing on a set of true variables which represent a unique, featured fingerprint for each sample.

This is a fast and easy technique with a high level of discrimination. The output consists of some sets or groups with the same affinities, separated by distances that indicate the degree of similarity. Simultaneously it provides predictive mathematical models for classifying any unknown sample not used previously.

Although initially it was wrongly called pseudoelectronic noise, some important differences arise from it. Firstly the ChemSensor method deals with a huge number of variables, up to about 500 . Since it is based on an ending gas chromatography mass detection, it produces a very reliable and consist outcome, not being affected by environmental humidity. The shortening of analysis time is also outstanding.

Mass data processing is further carried out with typical chemometric software that allows for dealing with such a big number of variables.

ChemSensor is a very useful technique for food analysis leading to the recognition of differences caused by the food itself or by its elaboration process, whatever the variation may be (Heiden et al, 2002; Carrasco, 2009).

On a routine basis, this technique can be performed using the volatile fraction of a sample (Kinton et al., 2003; Peña et al., 2003) as well as fatty acid methyl esters in the case of fat containing samples.

\section{MATERIALS AND METHODS}

\subsection{Sample supplying}

The starting material was backfat from Iberian pigs fattened on various farms and livestock farms in Extremadura, Andalusia and Salamanca (Spain). The animals were all Iberian breed, some of them pure Iberian and some crossed with Duroc in a $50 / 50$ ratio. The intensive feeding system used was in agreement with official standards and some of the customary handling of the farmers. Thus, pigs were fattened by the following types of food according to the quality standard: bellota, Recebo, ExtensiveFeeding (Cebo en campo) and Intensive Feeding. In some batches of pigs other variations were to be included due to special diets encountered: Finish-Recebo (Recebo postre), Fattened Intensive Feeding, Special Intensive Feeding. Samples were obtained during the 2009 and 2010 campaigns.

In 2009, we used a total of 207 mostly pure Iberian pigs with an average weight of about $160 \mathrm{~kg}$ (liveweight).
In 2010, we used a total of 205 pigs, as in the previous year, most of them lberian pure and with an average live-weight of about $160 \mathrm{~kg}$. This year, the set of intensive feeding-type showed variations from the standards, falling into these groups: Montanera, Recebo standard, Recebo postre, Valdesequerafield, oiled AECERIBER, Valdesequera-field especial, and Extensive-Intensive Feeding.

Samples of subcutaneous fat were taken from the lower back (tailbone) as the Spanish industry standard $(\mathrm{ASICI})$, proceeding to the microwave fat extraction.

\subsection{Sample arrangement}

Bacon samples obtained from the lumbar region were first cut with a knife to remove all traces of muscle, skin and parts other than the subcutaneous fat. Subsequently the fat was chopped and ground in a domestic type crusher. Once the fat was crushed it was poured into a microwaveable pot with a lid and put into the microwave on defrost position until the bacon turned brown and the fat had melted completely. The fat was then removed with a pipette and transferred to a small plastic tube. The tube was capped, labeled and stored at $-40^{\circ} \mathrm{C}$ for further methylation.

\subsection{Methylation of the sample}

After weighing $0.1 \mathrm{~g}$ of sample in a plastic tube with screw cap, $3 \mathrm{~mL}$ of a previously prepared solution of hexane and c9 internal standard (100 $\mathrm{mL}$-hexane $+50 \mu \mathrm{L}$ of internal standard c9) along with $200 \mu \mathrm{L}$ of transesterification reagent $(2 \mathrm{~N} \mathrm{KOH}$ in $\mathrm{MeOH}$, prepared from $13.202 \mathrm{~g}$ of $\mathrm{KOH}$ led to $100 \mathrm{~mL}$ in $\mathrm{MeOH}$ ) were added. Then, it was stirred in the vortex for $1 \mathrm{~min}$ and let stand for $5 \mathrm{~min}$. After this time, $0.5 \mathrm{~g}$ of $\mathrm{NaHSO} 4 . \mathrm{H} 2 \mathrm{O}$ were added, and the solution was mixed and centrifuged for 5 min at $3.000 \mathrm{rpm}$ at room temperature. A supernatant fraction of $1.5 \mathrm{ml}$ was taken and transferred to an amber glass GC vial and closed with a septum cap.

\subsection{Description of the analysis using the ChemSensor}

The analysis of the methyl esters of the fat was carried out using a gas chromatograph ChemSensor 4440 (Agilent Technologies, Palo Alto, CA, USA). This comprises a liquid auto-sampler of up to 100 samples, coupled to a quadrupole mass detector (MS 5973N) 235, working in full scan mode $(\mathrm{m} / \mathrm{z}$ $41-550$ ) to 1.43 scan / $\mathrm{s}$. The ionization energy is 70 eV. Once acquired, data were analyzed using the data analysis software Pirouette (v.3.11, Infometrix Inc., Bothell, WA).

Chemometric Analysis. The abundance matrix m / z obtained from the mass spectrum fragmentation of each sample was subjected to statistical analysis using the Independet Soft Class Analogy Modeling (SIMCA) of Infometricx Inc. which allows us to 


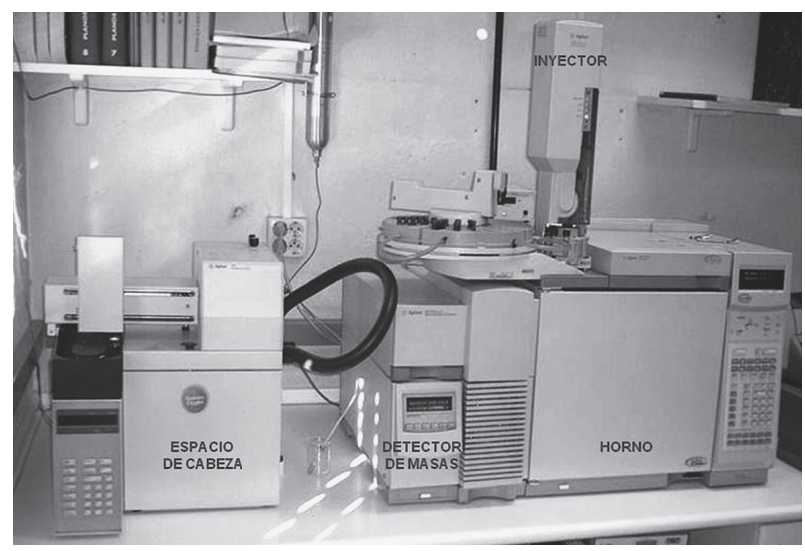

Figure 1

ChemSensor equipment.

obtain a classification pattern reaching a 95\% confidence level. SIMCA develops a Principal Component Analysis model to classify the samples into discrete categories (Peña et al., 2002). Based on the concept of proximity, the assumption made is that if a set of measurements of an unknown sample is very similar to a specific group, then this unknown sample should likely be a member of that group.

The data processing involves a first step of classification and determination of the mathematical model of prediction, based on known tested samples, and then a second step, in which the prediction model for unknown samples is applied. Among all analyzed samples, $75 \%$ of them were taken at random for obtaining the classification model and providing the homogeneous groups and the distances between them. Thus, this $75 \%$ set serves as the classification model. On the remaining $25 \%$ of samples, the prediction model is further obtained and applied.

\section{RESULTS}

Results are shown in the following tables for each year.

Thus, Table 1 shows the results of the classification of 2009 pigs. It is observed that there is a correct classification fit to the four official classes, being generally above $90 \%$. It should be noted that since it is a small number of samples, a single failure in classification can lead to a significant influence on the correct classifying percentage.

Table 2 shows the results of distances between groups of pigs from 2009. It is noted that the distances are greater among intensive feeding-type pigs than the other groups.

Table 3 shows the results of prediction for about $25 \%$ of pigs in 2009 . The prediction data shown in Table 3 are acceptable for three groups (around $85 \%$ ), whereas in the group called Cebo en campo (Extensive-Feeding) the prediction rate falls to $22 \%$. This fact is easily is explained by taking into account the small relative number of samples, and more remarkably, a wide variation of the intensive feeding used in the farms.

Below are the results corresponding to the year 2010. Table 4 shows the results of classification of 2010 pigs, grouping all items into the four groups of the official Standard. It is noted that the classification is very good, except for Recebo $(70 \%)$. This arises from a set of 9 Recebo pigs which were classified as Extensive Feeding (Cebo de campo), as we will discuss later.

Table 5 shows the results of distances between the groups of 2010 pigs. It is observed that separation distances have been enlarged for all groups except for Bellota - Recebo, in close agreement with the former classification table.

Table 1

Classification results for 2009 pigs according to the official Standard

\begin{tabular}{lccccc}
\hline Samples & $\begin{array}{c}\text { Classified } \\
\text { Bellota }\end{array}$ & $\begin{array}{c}\text { Classified } \\
\text { Recebo }\end{array}$ & $\begin{array}{c}\text { Classified } \\
\text { Extensive } \\
\text { Feeding }\end{array}$ & $\begin{array}{c}\text { Classified } \\
\text { Intensive } \\
\text { Feeding }\end{array}$ & $\begin{array}{c}\% \\
\text { Correct }\end{array}$ \\
\hline Bellota & 53 & 0 & 0 & 0 & 100 \\
Recebo & 0 & 53 & 1 & 0 & 98,15 \\
Extensive Feeding & 2 & 1 & 24 & 0 & $\mathbf{8 8 , 8 9}$ \\
Intensive Feeding & 0 & 0 & 0 & $\mathbf{2 2}$ & $\mathbf{1 0 0}$ \\
\hline
\end{tabular}

Table 2

Distances SIMCA model for 2009 pigs grouped following the Official Standard

\begin{tabular}{lcccc}
\hline & $\begin{array}{c}\text { Distances } \\
\text { to Bellota }\end{array}$ & $\begin{array}{c}\text { Distances } \\
\text { to }\end{array}$ & $\begin{array}{c}\text { Decebo } \\
\text { Extensive Feeding }\end{array}$ & $\begin{array}{c}\text { Distances to } \\
\text { Intensive Feeding }\end{array}$ \\
\hline Bellota & 0 & 0,97 & 0,66 & 3,19 \\
Recebo & 0,97 & 0 & 0,88 & 3,61 \\
Extensive Feeding & 0,66 & 0,88 & 0 & 3,36 \\
Intensive Feeding & 3,19 & 3,61 & 3,36 & 0 \\
\hline
\end{tabular}


Table 3

Predictions of SIMCA model for 2009 pigs grouped following the official Standard

\begin{tabular}{lccccc}
\hline & $\begin{array}{c}\text { Bellota } \\
\text { Forecast }\end{array}$ & $\begin{array}{c}\text { Recebo } \\
\text { Forecast }\end{array}$ & $\begin{array}{c}\text { Extensive } \\
\text { Feeding } \\
\text { Forecast }\end{array}$ & $\begin{array}{c}\text { Intensive } \\
\text { Feeding } \\
\text { Forecast }\end{array}$ & $\begin{array}{c}\% \\
\text { Correct }\end{array}$ \\
\hline Bellota & $\mathbf{1 6}$ & 0 & 2 & 0 & $\mathbf{8 8 , 8}$ \\
Recebo & 1 & $\mathbf{1 3}$ & 1 & 1 & $\mathbf{8 1 , 2}$ \\
Extensive Feeding & 2 & 5 & $\mathbf{2}$ & 0 & $\mathbf{2 2 , 2}$ \\
Intensive Feeding & 1 & 0 & 0 & $\mathbf{7}$ & $\mathbf{8 7 , 5}$ \\
\hline
\end{tabular}

Table 4

Classification results for 2010 pigs according to the Official Standard

\begin{tabular}{lccccc}
\hline & $\begin{array}{c}\text { Classified } \\
\text { Bellota }\end{array}$ & $\begin{array}{c}\text { Classified } \\
\text { Recebo }\end{array}$ & $\begin{array}{c}\text { Classified } \\
\text { Extensive } \\
\text { Feeding }\end{array}$ & $\begin{array}{c}\text { Classified } \\
\text { Intensive } \\
\text { Feeding }\end{array}$ & $\begin{array}{c}\% \\
\text { Correct }\end{array}$ \\
\hline Bellota & 37 & 1 & 0 & 0 & 97,37 \\
Recebo & 1 & 24 & 9 & 0 & 70,59 \\
Extensive Feeding & 0 & 0 & 55 & 0 & 100 \\
Intensive Feeding & 0 & 0 & 0 & 20 & 100 \\
\hline
\end{tabular}

Table 5

Distances SIMCA model for 2010 pigs grouped following the Official Standard

\begin{tabular}{lcccc}
\hline & $\begin{array}{c}\text { Distances } \\
\text { to Bellota }\end{array}$ & $\begin{array}{c}\text { Distances } \\
\text { to Recebo }\end{array}$ & $\begin{array}{c}\text { Distances to } \\
\text { Extensive Feeding }\end{array}$ & $\begin{array}{c}\text { Distances to } \\
\text { Intens Feeding }\end{array}$ \\
\hline Bellota & 0 & 1,56 & 3,48 & 4,95 \\
Recebo & 1,56 & 0 & 2,94 & 3,60 \\
Extensive Feeding & 3,48 & 2,94 & 0 & 2,85 \\
Intensive Feeding & 4,95 & 3,60 & 2,85 & 0 \\
\hline
\end{tabular}

Table 6 shows the results of prediction on the remaining $25 \%$ of 2010 pigs. The low percentage of correctly classified 2010 pigs grouped into the four categories of the official Standard is noteworthy. Undoubtedly, this is due to the actual dispersion of groups which leads to a messy mathematical model with low predictive ability.

To confirm what is described in the previous paragraph, we propose a new, sound classification suited to the actual starting groups of animals. Table 7 shows these results for the classification of 2010 pigs considering that it is actually seven distinct groups. There is a very good rating, with the only exception of two Bellota pigs that were classified as Recebo Standard and Finish-Recebo (Recebo postre), making the percentage drop to $88 \%$.

\section{DISCUSSION}

Tables 1, 2 and 3 show the results from pigs slaughtered in 2009. The classification is very good but the distances between groups are only significant for Bellota and Intensive Feeding
(Pienso) on one hand and also for Intensive Feeding (Pienso) and the rest of the classes on the other hand. The predictions are acceptable, except for Extensive Feeding (Cebo de campo). It should be kept in mind that in the case of intensive feeding on acorns, animals are very similar, but when only intensive feeding is used, the differences are bigger, in addition of the particular customs of the farmers.

Tables 4, 5 and 6 show the results of the classification of slaughtered pigs in 2010, showing a very good classification except for the Recebo group. Distances reflect a good separation power, but the prediction has not been good. This discrepancy is probably due to the differences that some batches have actually suffered in their diet: Bellota, Recebo, Finish-Recebo (recebo postre), Extensive Feeding (Cebo en campo), ExtensiveFattened Feeding (Pienso extensivo engrasado), Special-Extensive Feeding (Pienso extensivo especial) and Intensive Feeding (Pienso). This fact, although it might be considered as a failure in the experimental design, indeed reflects the reality of the Iberian industry, in which the only guarantee is the acorn supplying, leaving the intensive feeding to the stockbreeder's decision. 
Table 6

Predictions of SIMCA model for 2010 pigs grouped following the Official Standard

\begin{tabular}{lcccccc}
\hline & $\begin{array}{c}\text { Forecast } \\
\text { Bellota }\end{array}$ & $\begin{array}{c}\text { Forecast } \\
\text { Recebo }\end{array}$ & $\begin{array}{c}\text { Forecast } \\
\text { Extensive } \\
\text { Feeding }\end{array}$ & $\begin{array}{c}\text { Forecast } \\
\text { Intensive } \\
\text { Feeding }\end{array}$ & $\begin{array}{c}\text { No } \\
\text { Classif. }\end{array}$ & \% Right \\
\hline Bellota & $\mathbf{8}$ & 4 & 2 & 0 & 3 & $\mathbf{4 7 , 0 6}$ \\
Recebo & 2 & $\mathbf{5}$ & 8 & 0 & 0 & $\mathbf{3 3 , 3 3}$ \\
Extensive Feeding & 1 & 2 & $\mathbf{1 5}$ & 1 & 1 & $\mathbf{7 5 , 0 0}$ \\
Intensive Feeding & 0 & 0 & 2 & $\mathbf{4}$ & 0 & $\mathbf{6 6 , 6 7}$ \\
\hline
\end{tabular}

Table 7

Classification results for $\mathbf{2 0 1 0}$ pigs grouped according to their real diet

\begin{tabular}{lccccccccc}
\hline & $\begin{array}{l}\text { Clasific } \\
\text { Bellota }\end{array}$ & $\begin{array}{c}\text { Clasific } \\
\text { Recebo }\end{array}$ & $\begin{array}{c}\text { Clasif. } \\
\text { Finish- } \\
\text { Recebo }\end{array}$ & $\begin{array}{c}\text { Clasific. } \\
\text { Ext }\end{array}$ & $\begin{array}{c}\text { Clasific. } \\
\text { Feeding }\end{array}$ & $\begin{array}{c}\text { Clasific. } \\
\text { Fattd } \\
\text { Feeding } \\
\text { Special } \\
\text { Intens } \\
\text { Feeding }\end{array}$ & $\begin{array}{c}\text { Clasific. } \\
\text { Intens } \\
\text { Feeding } \\
\text { (official) }\end{array}$ & $\begin{array}{c}\text { No } \\
\text { clasiff. }\end{array}$ & $\begin{array}{c}\text { \% Right } \\
\text { Bellota }\end{array}$ \\
Recebo (official) & 38 & 0 & 0 & 0 & 0 & 0 & 0 & 0 & 100 \\
Finish-Recebo & 2 & 16 & 0 & 0 & 0 & 0 & 0 & 0 & 88,89 \\
Extensive Feeding & 2 & 0 & 15 & 0 & 0 & 0 & 0 & 0 & 88,24 \\
Extensive Fattened Feeding & 0 & 0 & 0 & 0 & 15 & 0 & 0 & 0 & 100 \\
Special Extensive Feeding & 0 & 0 & 0 & 0 & 0 & 18 & 0 & 0 & 100 \\
Intensive Feeding (official) & 0 & 0 & 0 & 0 & 0 & 0 & 20 & 0 & 100 \\
\hline
\end{tabular}

Table 8

SIMCA model distances of 2010 pigs grouped according to their real diet

\begin{tabular}{|c|c|c|c|c|c|c|c|}
\hline & $\begin{array}{l}\text { Distances } \\
\text { to Bellota }\end{array}$ & $\begin{array}{c}\text { Distances } \\
\text { to } \\
\text { Recebo }\end{array}$ & $\begin{array}{l}\text { Distances } \\
\text { to Finish- } \\
\text { Recebo }\end{array}$ & $\begin{array}{l}\text { Distances } \\
\text { to Ext } \\
\text { Feeding }\end{array}$ & $\begin{array}{l}\text { Distances to } \\
\text { Ext Fattened } \\
\text { Feeding }\end{array}$ & $\begin{array}{c}\text { Distances to } \\
\text { Special Ext } \\
\text { Feeding }\end{array}$ & $\begin{array}{c}\text { Distances } \\
\text { to Int } \\
\text { Feeding }\end{array}$ \\
\hline Bellota & 0 & 2,24 & 1,93 & 2,33 & 8,21 & 1,99 & 4,95 \\
\hline Recebo (Official) & 2,22 & 0 & 1,22 & 2,00 & 9,20 & 2,02 & 4,82 \\
\hline Finish-Recebo & 1,93 & 1,22 & 0 & 1,92 & 6,60 & 1,96 & 4,32 \\
\hline $\begin{array}{l}\text { Extensive } \\
\text { Feeding }\end{array}$ & 3,33 & 2,00 & 1,92 & 0 & 8,85 & 2,08 & 4,73 \\
\hline $\begin{array}{l}\text { Extensive } \\
\text { Fattened Feeding }\end{array}$ & 8,21 & 9,20 & 6,60 & 8,85 & 0 & 8,17 & 4,37 \\
\hline $\begin{array}{l}\text { Special Extensive } \\
\text { Feeding }\end{array}$ & 1,99 & 2,02 & 1,96 & 2,08 & 8,17 & 0 & 5,51 \\
\hline $\begin{array}{l}\text { Intensive Feeding } \\
\text { (official) }\end{array}$ & 4,95 & 4,88 & 4,32 & 4,73 & 4,37 & 5,51 & 0 \\
\hline
\end{tabular}

Therefore, when performing the analysis taking into account the actual class classification the percentage found was nearly $100 \%$.

\section{CONCLUSIONS}

We analyzed samples from two campaigns and observed differences in the predictive power of the models generated. The use of ChemSensor as a classification tool has proven to be reliable in all types of samples when grouped into four classes. In both campaigns, we have obtained selectivity greater than $85 \%$.

With the classification model generated by ChemSensor, some predictions have reached around $90 \%$ reliability in the case of samples of Intensive-Feeding and Bellota in 2009. In samples corresponding to Recebo animals reliability is more than $81 \%$, and then only in Extensive Feeding type does it drop to $22 \%$. With respect to 2010 samples, much lower prediction percentages were obtained 
Table 9

SIMCA model predictions of 2010 pigs grouped according to their real diet

\begin{tabular}{|c|c|c|c|c|c|c|c|c|c|}
\hline & $\begin{array}{c}\text { Forecast } \\
\text { Bellota }\end{array}$ & $\begin{array}{l}\text { Forecst } \\
\text { Recebo }\end{array}$ & $\begin{array}{c}\text { Forecst. } \\
\text { Finish- } \\
\text { Recebo }\end{array}$ & $\begin{array}{l}\text { Forecst. } \\
\text { Ext } \\
\text { Feeding }\end{array}$ & $\begin{array}{l}\text { Forecst. } \\
\text { Ext. Fattd } \\
\text { Feeding }\end{array}$ & $\begin{array}{l}\text { Forecst. } \\
\text { Special } \\
\text { Intens } \\
\text { Feeding }\end{array}$ & $\begin{array}{l}\text { Forecst.Int } \\
\text { Feedng } \\
\text { (official) }\end{array}$ & $\begin{array}{c}\text { No } \\
\text { clasiff. }\end{array}$ & $\%$ Right \\
\hline Bellota & 11 & 1 & 2 & 0 & 0 & 0 & 0 & 3 & 64,71 \\
\hline Recebo (Official) & 2 & 5 & 0 & 0 & 0 & 0 & 0 & 0 & 71,43 \\
\hline Finish-Recebo & 3 & 2 & 1 & 1 & 0 & 1 & 0 & 0 & 12,50 \\
\hline Extensive Feeding & 1 & 1 & 0 & 4 & 0 & 0 & 1 & 0 & 57,14 \\
\hline Extensive Fattened Feeding & 0 & 0 & 0 & 0 & 6 & 0 & 0 & 0 & 100,00 \\
\hline Special Extensive Feeding & 0 & 0 & 2 & 1 & 0 & 0 & 0 & 4 & 0 \\
\hline Intensive Feeding (official) & 0 & 0 & 0 & 0 & 0 & 0 & 6 & 0 & 100,00 \\
\hline
\end{tabular}

surely due to the lack of homogeneity of samples. This lack of homogeneity, together with the short number of samples, causes a single fault to greatly impact the percentage of correct forecasts.

To solve the problem of the dispersion of samples, an analysis has been done by grouping the samples into seven groups, including all the different intensive feeding types. In this way, almost $100 \%$ discrimination is obtained. The prediction power is lower, but in any case better than the four group model.

In view of the analytical work performed, it turns out that a classification Standard with too many categories will be very difficult to classify in a fair, reliable way. Apart from differences that are appreciated in the morphology of animals, a clear influence of the customary handling of farmers must be taken into account, along with the variability of the type of intensive feeding used. As a proposal, we suggest that the number of classes should be reduced to only two - Bellota and Intensive Feeding (Pienso), in order to definitely clarify the Iberian pig market.

With regards to the advantages of using ChemSensor over other techniques, we found great reliability, since it is a method based on gas chromatography and mass spectrometry (Peña et al, 2005). The determination of the relative abundance of a mass spectrum $\mathrm{m} / \mathrm{z}$ from 41 to 550 is equivalent to arranging up to 500 variables for each single sample. Pirouette chemometric software allows for a complete and reproducible data analysis.

Furthermore, this technique does not use electronic sensors which are susceptible to aging over time. Temperature and humidity conditions do not affect the results, thus gaining precision and reproducibility. The analysis time for each sample is very short, and the methyl ester derivatives of the fatty acids in the sample can be used or alternatively, a direct volatile compounds analysis can be performed.

This technique described for classifying samples of dead animals is also perfectly suited to the analysis of the elaborated products like hams or loins, making it possible to determine the type of intensive feeding supplied to the animal in such case. Chemsensor can also be a choice tool for food traceability tasks.

\section{ACKNOWLEDGEMENTS}

INIA project ref: 00026-C07-RTA2008-00.

\section{REFERENCES}

Carrasco J.A. 2009. Sistema de tipificación de la carne de animales y otros productos derivados en función de la especie, raza y/o alimentación. Patente de Invención ES 2308905. C.S.I.C., 23 octubre 2009.

Heiden AC, Gil C, Kinton VR, Pfannkoch EA, Ramos LS, Rohrback B. 2002. Classification of Food and Flavor: Samples using a Chemical Sensor. Gerstel Chemsensor Application: AppNote-2002-07

Kinton VR, Pfannkoch EA, Mabud MA, Dugar SM, Heiden, Gil C. 2003. Wine Discrimination using a Mass Spectral Based Chemical Sensor. Gerstel Chemsensor Application: AppNote-2003-02

Kinton VR, Whitecavage JA, Heiden AC, Gil C. 2004. Use of a Mass Spectral Based Chemical Sensor to Discriminate Food and Beverage Samples: Olive Oils and Wine as Examples. Gerstel Chemsensor Application: AppNote-2004-01. Simplifying chromatographic analysis of the volatile fraction of foods.

López-Feria S, Cárdenas S, García-Mesa JA, Valcárcel M 2008. Simple and rapid instrumental characterization of sensory attributes of virgin olive oil based on the direct coupling headspace-mass spectrometry. J. Chromatogr. A 1188, 308-313.

Marsili R. 2011. MS/Nose Instrumentation as a Rapid QC Analytical Tool. En: R Marsili R (Ed) Practical Analysis of Flavor and Fragrance Materials.

Peña F, Cardenas S, Gallego M, Valcarcel M. 2002. Characterization of olive oil classes using a chemSensor and pattern recognition techniques. J. Am. Oil Chem. Soc. 79, 1103-1108.

Peña F, Cárdenas S, Gallego M, Valcárcel M. 2003. Direct sampling of orujo oil for determining residual hexane by using a ChemSensor. .J. Am. Oil Chem. Soc. 80, 613-618. 
Peña $F$, Cárdenas S, Gallego $M$, Valcárcel $M$. 2005. Direct olive oil authentication: Detection of adulteration of olive oil with hazelnut oil by direct coupling of headspace and mass spectrometry, and multivariate regression techniques. J. Chromatogr. A, 1074, 215-221.
Pérez Pavón JL, del Nogal Sánchez M, García Pinto C, Fernández Laespada ME, Moreno Cordero B, Guerrero Peña A. 2006. Strategies for qualitative and quantitative analyses with mass spectrometry-based electronic noses. Trends Anal. Chem. 25, 257-266.

Recibido: $16 / 10 / 12$ Aceptado: 26/1/13 